\title{
THE RATE OF THE CIRCULATION OF THE BLOOD IN NORMAL RESTING INDIVIDUALS*
}

By H. FIELD, JR., A. V. BOCK, E. F. GILDEA, AND F. L. LATHROP

(From the Medical Laboratories of the Massachusetts General Hospital, Boston, Mass.)

(Received for publication, September 10, 1924)

This paper describes two allied methods for the determination of the rate of blood flow which have yielded consistently reproducible results in untrained subjects. The data obtained in forty experiments on twenty-one normal resting individuals are presented in tabular form. The first method is suitable for use with subjects having practically any type of pathology but in the resting condition only. The second method is inapplicable when the subject has a pulmonary lesion preventing ventilation of part of the alveoli or a cardiac defect permitting mixture of arterial and venous blood. With these restrictions, however, this method should be useful as it can be carried out in a short time, with a high degree of accuracy and under varying conditions of activity.

\section{METHOD I}

Several investigators have studied the circulation rate, determining the gases in the mixed venous blood by some procedure in which the lungs are used as an aerotonometer, and those in the arterial blood indirectly from the alveolar air or directly by analysis of blood obtained by arterial puncture. Burwell and Robinson, in a contemporary publication (1) have reviewed the literature of the subject and a complete bibliography will not be given here.

The method of Christianson, Douglas, and Haldane (2) is difficult to apply to patients but, in suitable subjects, should yield results of the correct order of magnitude. It consists in the inhalation of a mixture of $\mathrm{CO}_{2}$ and air (oxygen was used instead of air in a few ex-

*The expenses of this research were defrayed in part by the Proctor Fund and by the Tutorial Fund of Harvard University. 
periments) of such proportions that two alveolar air samples taken at the end of half and complete expirations at five second intervals subsequent to the inhalation show no change or but slight change in $\mathrm{CO}_{2}$ content, indicating that they were in equilibrium with the $\mathrm{CO}_{2}$ of the mixed venous blood. This requires the use of several mixtures in order to obtain one that satisfies the above requirement or two that lie upon either side of the venous $\mathrm{CO}_{2}$ tension and sufficiently close to it. As the originators pointed out, the figure thus obtained represents the tension of $\mathrm{CO}_{2}$ in the mixed venous blood after it has become oxygenated without change in its $\mathrm{CO}_{2}$ content, and a correction must be applied in order to obtain the actual $\mathrm{CO}_{2}$ tension of the venous blood. This, they verified by experiments in which both the $\mathrm{CO}_{2}$ and $\mathrm{O}_{2}$ tensions were obtained simultaneously by "straddling" as described above. They determined the $\mathrm{CO}_{2}$ content of the arterial blood by applying the $\mathrm{CO}_{2}$ tension observed in the alveolar air by the Haldane-Priestly method (3) to the same $\mathrm{CO}_{2}$ dissociation curve to which the venous tension was applied. This curve did not need to be determined in each experiment for they assumed that, although the heights of different curves vary, the slopes are approximately the same.

Y. Henderson and Prince (4) pointed out that this method of obtaining the mixed venous $\mathrm{CO}_{2}$ tension was cumbersome and that the same result might be arrived at much more simply by a procedure in which expired air was inhaled from a rubber bag, held in the lungs for five seconds and exhaled into the bag. After this had been repeated several times the $\mathrm{CO}_{2}$ content of the mixture rose to a height at which it was constant through further repetitions. The figure thus obtained corresponded to $\mathrm{CO}_{2}$ tension of oxygenated mixed venous blood or, as Y. Henderson later (5) called it, the "virtual" venous $\mathrm{CO}_{2}$ tension.

Meakins and Davies (6) stated that they obtained indifferent results with the Henderson and Prince method of obtaining the mixed venous $\mathrm{CO}_{2}$ tension. This, they ascribed to improper mixing of the gasses in the lungs after a single inspiration and varied the procedure by having the subject exhale as deeply as possible, inhale from a bag of expired air, exhale deeply into the bag, inhale from the bag a second time, and finally exhale forcibly into the bag. A portion of the last of the air of the final expiration was removed into a Haldane gas samp- 
ling tube through a side tube interposed between the mouthpiece and the bag. They also noted that, in patients, determinations of the arterial $\mathrm{CO}_{2}$ content by direct analysis of arterial blood were much more satisfactory than those made by interpolation of the alveolar $\mathrm{CO}_{2}$ tension on the $\mathrm{CO}_{2}$ dissociation curve.

Burwell and Robinson (1) have developed a method with which, by diluting the residual air with a proper mixture of $\mathrm{CO}_{2}, \mathrm{O}_{2}$, and $\mathrm{N}_{2}$, preliminary to the rebreathing, they obtain air in equilibrium with both the $\mathrm{O}_{2}$ and $\mathrm{CO}_{2}$ of a mixed venous blood. By analysis of the subject's blood equilibrated at body temperature in tonometers filled with gas from the rebreathing bag they obtain both the $\mathrm{CO}_{2}$ and $\mathrm{O}_{2}$ content of the mixed venous blood. Having analyzed directly both the $\mathrm{CO}_{2}$ and $\mathrm{O}_{2}$ of the arterial blood, they are able to determine the circulation rate from both gases and also the "respiratory quotient" of the blood. They thus have a double check on the accuracy of the procedure.

In our methods the $\mathrm{CO}_{2}$ only of the arterial and mixed venous bloods is determined. In the first method the $\mathrm{CO}_{2}$ content of arterial blood is determined both by direct analysis and by interpolation of the alveolar $\mathrm{CO}_{2}$ tension on the $\mathrm{CO}_{2}$ dissociation curve, determined in each experiment and corrected to 95 per cent oxygen saturation. The assumption that the arterial blood has an oxygen saturation of 95 per cent is, in all normal and in most pathological subjects, close enough to the actual condition so as to lead to no appreciable error. When the figures thus obtained by two different methods agree reasonably well there is afforded sufficient check as to the accuracy of the determinations. The case of disagreement will be discussed later.

The $\mathrm{CO}_{2}$ content of the mixed venous blood, we obtain by applying to the $\mathrm{CO}_{2}$ dissociation curve for completely oxygenated blood the $\mathrm{CO}_{2}$ tension obtained by the Henderson and Prince method modified in the following particulars. The equilibration time is prolonged to 15 seconds which is quite safe in the resting subject. The suggestion of Meakins and Davies (6) of rebreathing instead of holding the mixture in the lungs has been adopted but the subjects rebreathe four or five times instead of twice. This may be done in fifteen seconds without noticeable exertion. A mixture of 6 per cent $\mathrm{CO}_{2}$ with 94 per cent $\mathrm{O}_{2}$ rather than expired air is used for the rebreathing. Finally about 
$12 \mathrm{cc}$. of $\mathrm{CO}_{2}$ is generally added to the mixture between rebreathing periods in order to compensate for the diluting effect of the residual lung air and to raise the $\mathrm{CO}_{2}$ tension to that of the oxygenated mixed venous blood very quickly. This addition of $\mathrm{CO}_{2}$ between rebreathing periods is not essential in the case of resting subjects, at least, but it has given us more confidence in the equilibrations, especially in experiments with untrained subjects and in experiments during exercise when the more rapid blood flow necessitates reducing the period of rebreathing to five or ten seconds.

The use of a mixture with a high $\mathrm{O}_{2}$ content for the rebreathing seems essential if the assumption is to be made that the $\mathrm{CO}_{2}$ tension obtained is that of oxygenated venous blood. We have found $\mathrm{O}_{2}$ tensions of from 65 to $75 \mathrm{~mm}$. of $\mathrm{Hg}$ in the gas mixtures after several rebreathing periods when the bag was filled in the beginning with expired air. Such tensions would be insufficient to oxygenate the blood completely even if complete equilibrium between it and the oxygen of the alveolar air were attained. But because of the slowness of $\mathrm{O}_{2}$ diffusion and because of inequalities of ventilation in different parts of the lungs together with the inability of the blood to equalize the $\mathrm{O}_{2}$ effects of such varying ventilation, as pointed out by Haldane (7), the $\mathrm{O}_{2}$ tension of blood leaving the lungs is considerably less than that of the alveolar air. The use of expired air for the rebreathing and the calculation of results on the assumption that complete oxygenation of the blood is thereby permitted causes an error that cannot readily be corrected because oxygenation will not be complete and the amount of unsaturation of the blood will not be known. By the use of high oxygen mixtures we have obtained figures for $\mathrm{CO}_{2}$ tensions from 0.5 to $1.0 \mathrm{~mm}$. of $\mathrm{Hg}$, higher than those obtained by rebreathing expired air. Table 1 shows the results of experiments in which bags containing the high oxygen mixture and expired air were used at alternating periods.

A mixture containing at the beginning 94 per cent of $\mathrm{O}_{2}$ may be used for five or six periods of rebreathing before the $\mathrm{O}_{2}$ tension falls below about $150 \mathrm{~mm}$. of $\mathrm{Hg}$. At this tension, with the increased depth of respiration used in the experiment, there will be no significant oxygen unsaturation of the blood passing through the lungs. As, under the conditions outlined above, the $\mathrm{CO}_{2}$ tension remains 
TABLE 1

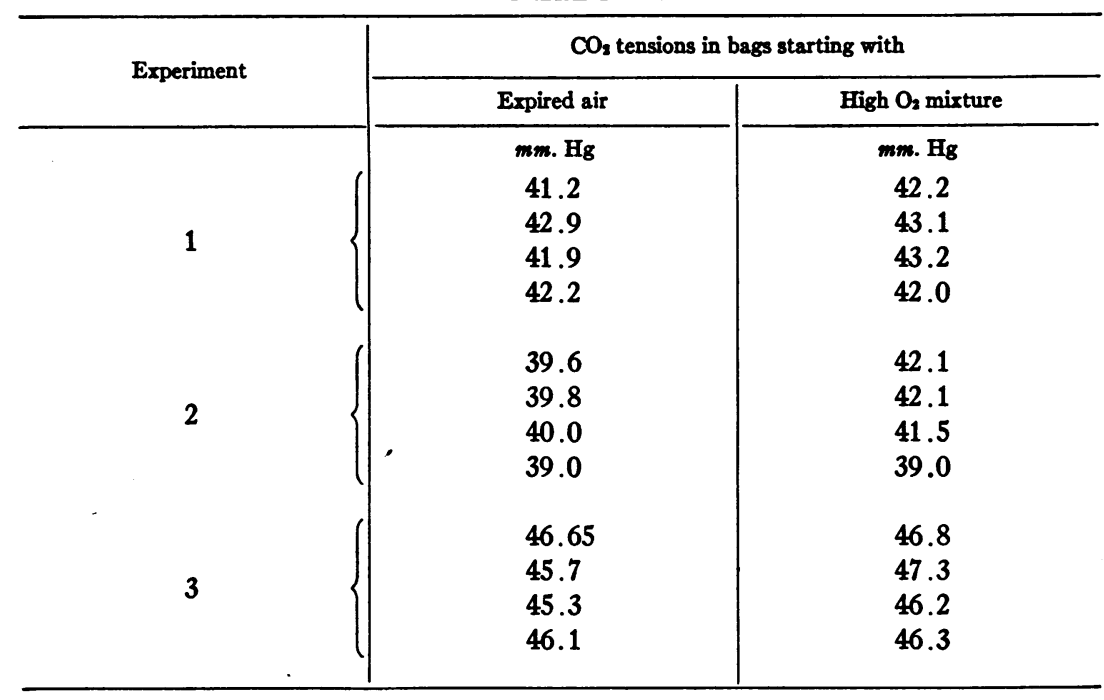

TABLE 2

\begin{tabular}{|c|c|c|}
\hline \multirow{2}{*}{ Experiment } & \multicolumn{2}{|c|}{ "Virtual" venous $\mathrm{CO}_{2}$ tension } \\
\hline & $12 \mathrm{cc} . \mathrm{CO}_{2}$ added between periods & No $\mathrm{CO}_{2}$ added \\
\hline 1 & $\begin{array}{l}m m . \mathrm{Hg} \\
38.4 \\
40.1 \\
39.1\end{array}$ & $\begin{array}{c}\text { mm. Hg } \\
38.7 \\
39.5 \\
37.8\end{array}$ \\
\hline Average............. & 39.2 & 38.7 \\
\hline 2 & $\begin{array}{l}40.6 \\
41.3 \\
40.7\end{array}$ & $\begin{array}{l}41.7 \\
40.9 \\
41.5\end{array}$ \\
\hline Average............. & 40.9 & 41.4 \\
\hline 3 & $\begin{array}{l}44.2 \\
44.7 \\
44.8 \\
44.35\end{array}$ & $\begin{array}{l}45.2 \\
44.7 \\
44.7\end{array}$ \\
\hline Average.............. & 44.5 & 44.9 \\
\hline
\end{tabular}


practically constant from the second to the fifth or sixth rebreathing period, samples may be taken after each of four or five periods without renewing the gas mixture. This is ordinarily sufficient to give a satisfactory average.

For the validity of the assumptions that oxygenation of the venous blood, and $\mathrm{CO}_{2}$ equilibrium between it and the gas mixture rebreathed are complete, there are several bits of evidence. The fact that the addition of $\mathrm{CO}_{2}$ to the mixture between periods of rebreathing did not effect the $\mathrm{CO}_{2}$ tensions obtained is indication of the completeness of $\mathrm{CO}_{2}$ equilibrium. Table 2 shows the results of experiments in which two bags containing the same high oxygen mixture at the beginning were used alternately. To one of them $12 \mathrm{cc}$. of $\mathrm{CO}_{2}$ was added between periods. To the other there was no addition of $\mathrm{CO}_{2}$.

The fact that variations in the $\mathrm{O}_{2}$ tension above $150 \mathrm{~mm}$. of $\mathrm{Hg}$. have no effect on the $\mathrm{CO}_{2}$ tensions obtained is evidence of the completeness of the oxygenation of the blood even at the lower tensions of $\mathrm{O}_{2}$. Table 3 shows the values of both $\mathrm{CO}_{2}$ and $\mathrm{O}_{2}$ in several series of determinations.

We endeavored to secure direct evidence by analysis of blood withdrawn from an artery during the last five seconds of a rebreathing period. Such blood should be completely oxygenated and should have the same $\mathrm{CO}_{2}$ tension as the air in the rebreathing bag. At the first attempt, made during the third period that the mixture was rebreathed, the blood was not obtained before the end of the fifteen second interval so that its $\mathrm{CO}_{2}$ content was increased by the second return of unventilated blood. It was, however, 99 per cent saturated with $\mathrm{O}_{2}$-complete within the error' of the analysis or near enough so as to have no appreciable effect on the $\mathrm{CO}_{2}$ tension.

At a second attempt sufficient blood was not obtained for both $\mathrm{O}_{2}$ and $\mathrm{CO}_{2}$ analyses. It appeared brightly arterial and the $\mathrm{CO}_{2}$ content, determined by direct analysis, was within 0.2 volume per cent of that estimated by interpolation of the $\mathrm{CO}_{2}$ tension of the mixture that was rebreathed on the $\mathrm{CO}_{2}$ dissociation curve for oxygenated blood subsequently determined. Table 4 is a protocol of this experiment.

The $\mathrm{CO}_{2}$ elimination was calculated from the $\mathrm{O}_{2}$ consumption determined with the Benedict portable metabolism apparatus, having our subjects in the post absorptive condition and assuming a respira- 
tory quotient of 0.81 . This seems to be by far the simplest and fully as accurate as any method except the use of the closed chamber.

TABLE 3

\begin{tabular}{|c|c|c|}
\hline \multirow{2}{*}{ Experiment } & \multicolumn{2}{|c|}{ Gas mixture after rebreathing } \\
\hline & $\mathrm{O}_{3}$ tension & $\mathrm{CO}_{2}$ tension \\
\hline & $m m . \mathrm{Hg}$ & $m m . \mathrm{Hg}$ \\
\hline 1 & $\begin{array}{l}347 \\
268 \\
246 \\
184\end{array}$ & $\begin{array}{l}46.6 \\
46.15 \\
46.8 \\
46.55\end{array}$ \\
\hline 2 & $\begin{array}{l}308 \\
271 \\
197 \\
151\end{array}$ & $\begin{array}{l}47.9 \\
47.8 \\
48.6 \\
48.2\end{array}$ \\
\hline 3 & $\begin{array}{l}284 \\
259 \\
192 \\
174\end{array}$ & $\begin{array}{l}42.8 \\
43.0 \\
43.0 \\
42.7\end{array}$ \\
\hline 4 & $\begin{array}{l}423 \\
343 \\
232 \\
158\end{array}$ & $\begin{array}{l}44.1 \\
44.7 \\
46.4 \\
44.7\end{array}$ \\
\hline
\end{tabular}

TABLE 4

\begin{tabular}{|c|c|c|}
\hline & $\mathrm{CO}_{2}$ tensions & $\mathrm{CO}_{2}$ content \\
\hline 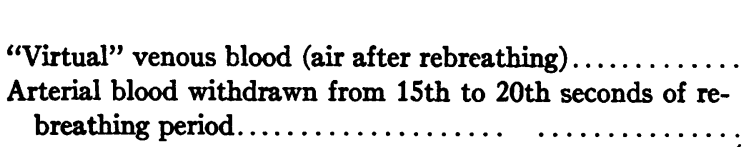 & $\begin{array}{c}m m . \mathrm{Hg} \\
47.3\end{array}$ & Vol. per cent \\
\hline $\begin{array}{l}\text { Points determined on } \mathrm{CO}_{2} \text { dissociation curve for oxygenated } \\
\text { blood } \ldots \ldots \ldots \ldots \ldots \ldots \ldots \ldots \ldots \ldots \ldots \ldots \ldots \ldots \ldots \ldots \ldots \ldots \ldots \ldots\end{array}$ & $\begin{array}{l}44.5 \\
41.7 \\
44.75\end{array}$ & $\begin{array}{l}49.1 \\
47.7 \\
48.8\end{array}$ \\
\hline $\begin{array}{l}\text { Arterial blood (by interpolation on dissociation curve)...... } \\
\text { Height of dissociation curve at } 47.3 \mathrm{~mm} \text {. of } \mathrm{Hg} \text {. tension.... }\end{array}$ & 46.8 & 50.1 \\
\hline
\end{tabular}

Variations in the respiration while the subject is on the apparatus can influence the oxygen consumption but little, while the $\mathrm{CO}_{2}$ elimination and the respiratory quotient will be very seriously effected. 
Consideration of table 5 will convince one of this latter statement. The first six columns are copied from the paper of Hendry, Carpenter and Emmes (8). Each figure represents the average respiratory quotient in two of twelve periods done on each subject in a morning.

The average respiratory quotient for the seventeen subjects is 0.814. In three of the subjects the values obtained for the different periods varied so greatly and some were so far from the usual postabsorptive value that not even the average of twelve periods may be assumed to represent the actual quotients. Excluding these three subjects, J. A. C., H. O., and P. G. H., the average quotient of the remaining fourteen is 0.809 . Without much doubt an assumed respiratory quotient of 0.81 would have approached the actual conditions in the three subjects named more closely than did the average of twelve determinations.

Also, it will be apparent that even in the remaining fourteen subjects it would have required considerably more than two periods to determine a respiratory quotient closer to the actual than an assumed value of 0.81 . In none of these fourteen did the actual quotient, if that is assumed to be represented by the average of the twelve periods, differ from 0.81 by more than 0.023 and the average deviation from 0.81 was only 0.014 . On the other hand in eleven of the fourteen there was a maximum deviation of the average of two periods from the average of the twelve periods of more than 0.02 and for the fourteen the average maximum deviation was 0.032 . The average deviation of the average of two periods from that for the individual was 0.018 throughout the fourteen. This occurred despite the fact that the determinations were done in a laboratory where every possible care and precaution to eliminate errors were taken. They represent a degree of accuracy that will not be readily duplicated.

The order in which the various specimens and data are collected in our procedure is of some importance. The experiment must be so arranged as to consume a minimum amount of time as it is found that if it is too prolonged the level of respiratory control may change so that both the alveolar and "virtual" venous $\mathrm{CO}_{2}$ tensions become either greater or less than at the beginning of the experiment or at the time when the sample of arterial blood is withdrawn. Experiments Nos. 1 and 2 of table 2 illustrate this change in level. The metabo- 
FIELD, BOCK, GILDEA, AND LATHROP

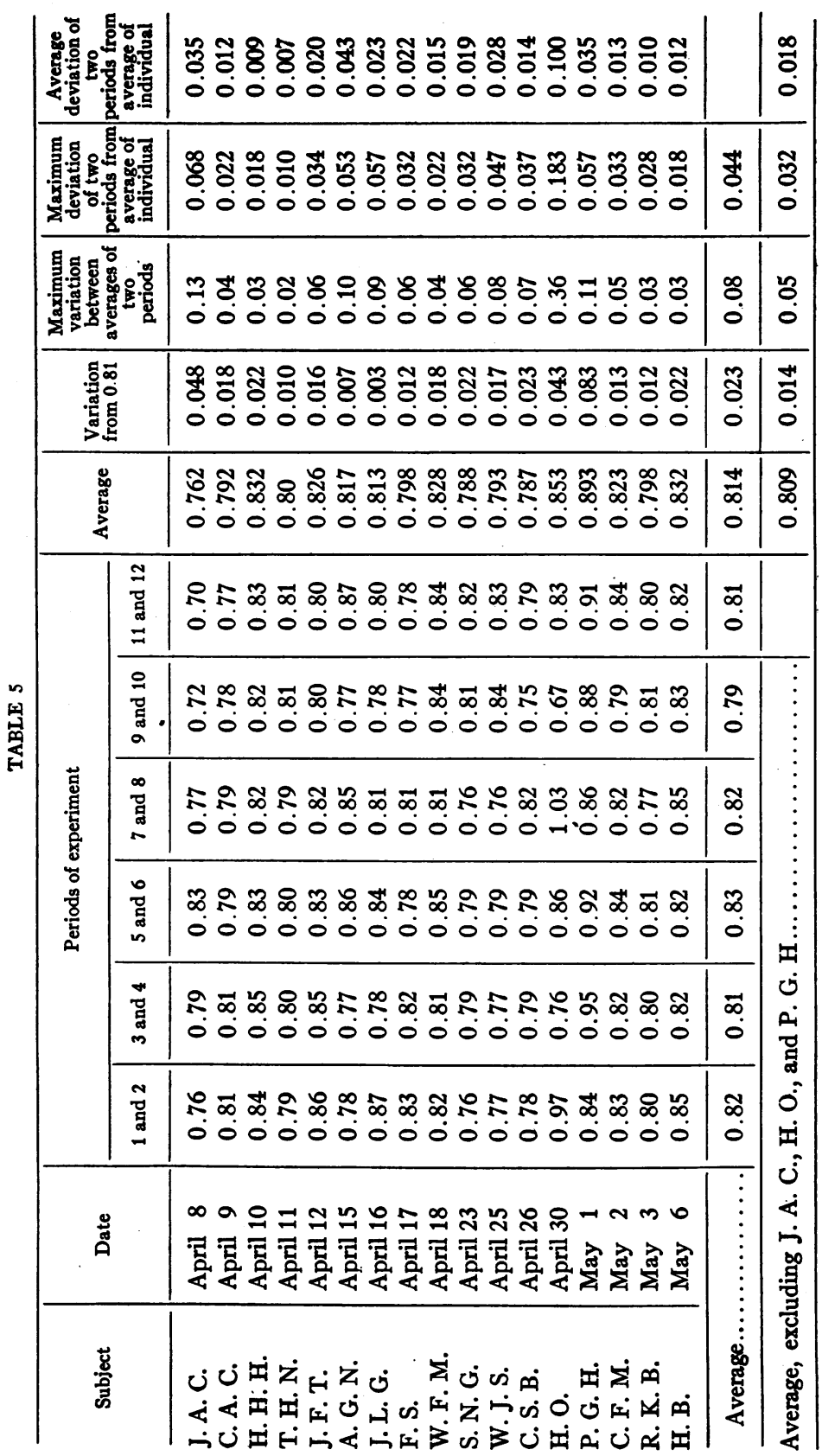


lism is the last thing to be done as it is found that the abnormality of ventilation which is very apt to occur while the subject is connected with the apparatus is accompanied by more rapid readjustment of base in the blood than had been thought possible.

After a rest period of from 45 to 60 minutes, one or two alveolar air samples are collected. The first of five 15 second periods of rebreathing from the bag to obtain the oxygenated venous $\mathrm{CO}_{2}$ tension is then begun. Samples are removed from the bag after each of the last four of these periods. If more samples are desired the gas mixture in the bag must be renewed. An alveolar air sample is collected one minute before and again three minutes after each rebreathing period. Between periods 2 and 3 the radial artery is anesthetized with novocaine and between periods 3 and 4 the sample of arterial blood is withdrawn. This entire procedure may usually be completed within about thirty minutes.

It is not necessary to discuss the details of our technic as they have been described in previous papers $(9,10)$. Suffice it to say, largely in recapitulation, that the $\mathrm{CO}_{2}$ dissociation curve for oxygenated blood was determined in each experiment. Sufficient arterial blood was usually obtained for this purpose. When such was not the case and the supply was supplemented by venous blood drawn without stasis no significant difference between arterial and venous blood was noted. The alveolar and "virtual" venous $\mathrm{CO}_{2}$ tensions and the $\mathrm{CO}_{2}$ content of arterial blood were determined by direct analysis. The $\mathrm{CO}_{2}$ content of the mixed venous blood and the $\mathrm{CO}_{2}$ tension of the arterial blood were estimated by interpolation of the corresponding $\mathrm{CO}_{2}$ tension and content on the $\mathrm{CO}_{2}$ dissociation curves for blood completely oxygenated and 95 per cent oxygenated, respectively.

Only the collection of alveolar air samples requires further comment. We have recently presented theoretical and experimental evidence (11) indicating that the effective alveolar $\mathrm{CO}_{2}$ tension is very closely approximated by that of the Haldane-Priestly sample collected at the end of normal expiration rather than by the average of samples collected at the end of both expiration and inspiration. We believe that the latter procedure yields results that are 1 to $2 \mathrm{~mm}$. of $\mathrm{Hg}$ tension too low. Consequently only expiratory alveolar air samples have been taken. 


\section{METHOD II}

In experiments done according to the method described above there have been discrepancies between the arterial and the alveolar $\mathrm{CO}_{2}$ tensions. In most instances these discrepancies have been small and that fact is indicative of the accuracy of the determinations, it making little difference, in the majority of cases, whether the circulation rate is calculated using the arterial $\mathrm{CO}_{2}$ content directly determined or that estimated from the alveolar $\mathrm{CO}_{2}$ tension. In a few experiments, however, the discrepancies have been large. In such a case it is difficult to know which is the correct value to use.

Discrepancies between the alveolar and arterial $\mathrm{CO}_{2}$ tensions of even greater magnitude than we have found have been observed by previous workers $(12,13)$. They have usually been ascribed to incompleteness of $\mathrm{CO}_{2}$ equilibrium between alveolar air and arterial blood but, as has been shown by Van Slyke (14), this can hardly be the correct explanation. $\mathrm{CO}_{2}$ diffusion being 20 to 30 times as rapid as $\mathrm{O}_{2}$ diffusion there can never be any considerable difference between alveolar and arterial $\mathrm{CO}_{2}$ tensions while there is adequate oxygenation of the arterial blood. The difference observed can be readily explained as the effect of variations in ventilation between the times of collection of the samples of alveolar air and arterial blood. Inasmuch as the $\mathrm{CO}_{2}$ tension of the alveolar air is inversely proportional to the pulmonary ventilation, the $\mathrm{CO}_{2}$ elimination remaining constant, it is apparent that the respirations need vary but little to change this tension considerably.

Believing this to be the case, we have devised the second method in order to avoid the error due to such variations in alveolar $\mathrm{CO}_{2}$ tension and to provide a more rapid means of estimating the rate of blood flow. The object of this method is to obtain simultaneous values of the alveolar and "virtual" $\mathrm{CO}_{2}$ tensions. This we have been able to do by means of a simple piece of apparatus using a three way and a two way valve (Fig. 1). The three way valve (a) to which a mouth piece is attached permits the subject to breath either through the outlet $(b)$ into the outside air or through the rest of the apparatus. The two way valve $(c)$ may be turned either into a long tube $(d)$ which has a side tube $(e)$ close to the valve for collection 
of alveolar air samples or into a rubber bag $(f)$ containing the $\mathrm{CO}_{2}$ and $\mathrm{O}_{2}$ mixture for equilibration with oxygenated venous blood.

During the experiment the subject has the mouthpiece in his mouth with the three way valve $(a)$ turned so that he is breathing into the outside air. The two way valve $(c)$ is turned into the tube $(d)$. At the end of a normal expiration the valve $(a)$ is turned so that the subject may make a forced expiration through the valve $(c)$ and the tube $(d)$. At the end of the forced expiration the valve $(c)$ is turned so that the subject may breathe from the bag $(f)$. He rebreathes the gas mixture in the bag four or five times and then near the end of the 15 second period exhales deeply into the bag. At the end of this

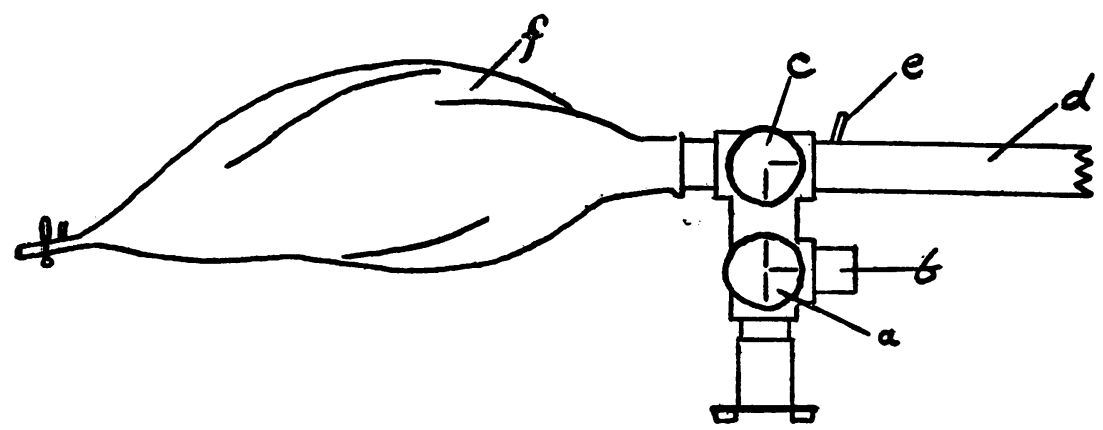

Fig. 1. Apparatus for Collection of Alveolar and "Virtual" Venous AIR SAMPLes.

expiration the valve $(a)$ is again turned so that the outside air is breathed. A sample of alveolar air is taken into a Haldane sampling tube from the side tube $(e)$, (this may be done during the rebreathing from the bag, the sampling tube being previously attached to the apparatus) and a sample of the air in the bag is taken. Between periods about $12 \mathrm{cc}$. of $\mathrm{CO}_{2}$ are usually introduced into the bag.

In this way there is obtained from the bag air that is in $\mathrm{CO}_{2}$ equilibrium with the oxygenated venous blood that was in the peripheral circulation at the time when the alveolar air sample was taken. The two samples thus yield simultaneous values. The circulation rate remaining the same, variations in pulmonary ventilation should be reflected in both the arterial and venous $\mathrm{CO}_{2}$ tensions and the difference between the two should not be effected thereby. This is true, however, only 
within certain limits. The tissues serving as a reservoir for $\mathrm{CO}_{2}$, the venous $\mathrm{CO}_{2}$ tension follows changes in the arterial $\mathrm{CO}_{2}$ tension comparatively slowly. Hence if there has been a marked change in ventilation immediately preceding the collection of the samples an incorrect value for the difference between the arterial and venous $\mathrm{CO}_{2}$ tensions will be obtained. In order to reduce the probability of this error we have had our subjects keep the mouthpiece in place throughout the time that the samples were being collected. The biggest change in ventilation occurs when the subject shifts from normal nose breathing to breathing through the mouthpiece of the apparatus. Once the breathing has become steady at the new level and there has been time for adjustment of the $\mathrm{CO}_{2}$ tension of the tissues to it, the change has no effectt on the difference between arterial and venous

\begin{tabular}{c|c}
\multicolumn{2}{c}{ TABLE 6} \\
\hline Tension range & Factor for slope of $\mathrm{CO}_{2}$ dissociation curve \\
\hline$m m . \mathrm{Hg}$ & \\
45 to 50 & 0.42 \\
40 to 50 & 0.44 \\
40 to 45 & 0.46 \\
35 to 40 & 0.48 \\
30 to 40 & 0.51 \\
\hline
\end{tabular}

$\mathrm{CO}_{2}$ tensions. Minor differences in ventilation are followed by rapid enough adjustment so that values of a good degree of uniformity may usually be obtained and the average of several of these values should give a very accurate figure.

The calculation of the circulation rate from the figures so obtained is simple. One millimeter is substracted from the average difference in $\mathrm{CO}_{2}$ tension between the alveolar air and the oxygenated venous blood. This is because of the small difference in $\mathrm{CO}_{2}$ tension that probably exists between the alveolar air and arterial blood for reasons discussed in another paper (11) and because arterial blood is only about 95 per cent saturated with oxygen while the high oxygen mixture used results in practically complete oxygen saturation of the blood passing through the lungs during the rebreathing. This figure, of course, is only an estimate but it is probably nearly correct and an error of a few tenths of a millimeter would make but little difference 
in the final result. The corrected figure for tension difference is then applied to a standard $\mathrm{CO}_{2}$ dissociation curve for oxygenated blood to reduce it to terms of cubic centimeters. This may be most readily done by multiplying by a factor corresponding to the slope of the dissociation curve. We have not assumed a straight line dissociation curve although such an assumption would not cause a very great error. We have used a set of factors corresponding to the different ranges of tension over the $\mathrm{CO}_{2}$ dissociation curve of A. V. B., published elsewhere (10). Table 6 contains these factors. They are accurate enough for use with all subjects whose blood contains normal amounts of base and hemoglobin. In other subjects the slope of the curve must be determined otherwise. The data in hand then permit the application of Fick's principle by which the figure for the blood flow is obtained.

\section{DISCUSSION}

Forty determinations of the circulation rate have been made on twenty-one individuals, all of them young adults, three of them females. The protocols of these experiments are contained in Tables 7 and 8. In the instances where repeated determinations have been made on the same individual they usually agree reasonably well. In the majority of them the variation is a fraction of a liter. In a few cases it is several liters. Examination of the data of such experiments leads one to conclude that the variations are in large part real. Indeed, they are to be expected for it is probable that the circulation rate is influenced by many factors that are beyond control of our attempts to secure basal conditions. One would expect, for instance, that the circulation rate would be more variable than the basal metabolic rate.

When the repetitions have been made by the different methods the agreement is again good. In general the figures obtained by the second method are somewhat lower than those by the original one. Of the two we consider that the second method is somewhat less liable to error because of the simultaneous nature of the determinations of alveolar and venous $\mathrm{CO}_{2}$ tensions.

Concerning the normal circulation rate under basal conditions the data herein reported would indicate that the contenders for a 


\begin{tabular}{|c|c|}
\hline 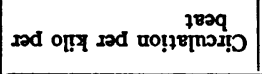 & ษ \\
\hline 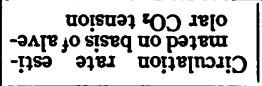 & 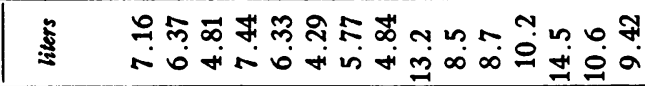 \\
\hline 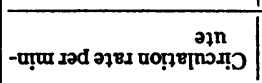 & 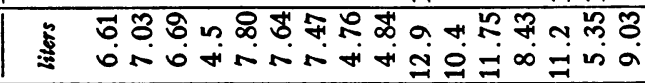 \\
\hline 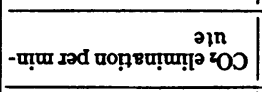 & 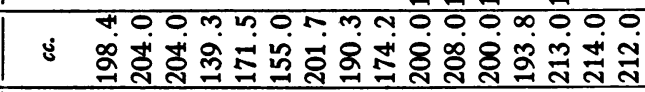 \\
\hline jo $\begin{array}{c}\text { poofq snoura } \\
\text { to }\end{array}$ & 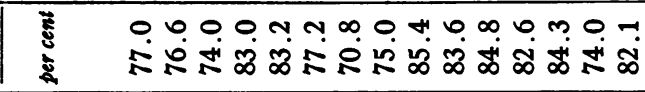 \\
\hline 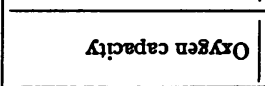 & | \\
\hline  & 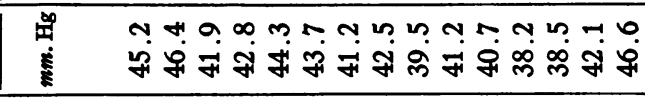 \\
\hline 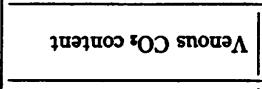 & 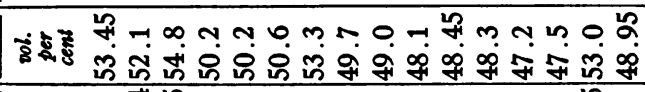 \\
\hline 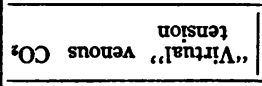 &  \\
\hline 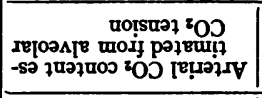 & 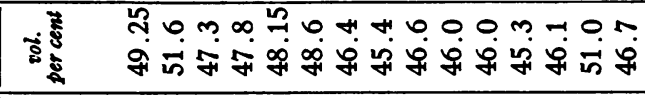 \\
\hline 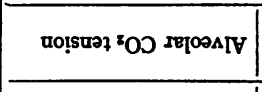 & 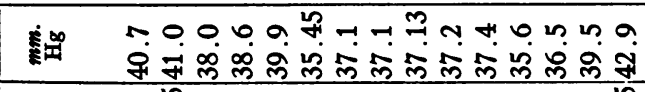 \\
\hline  & 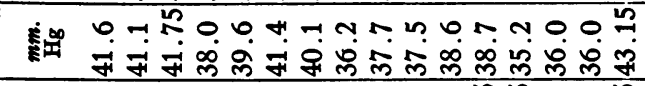 \\
\hline 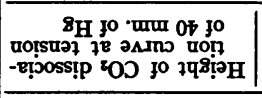 & 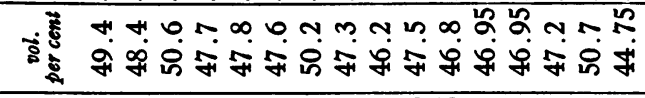 \\
\hline 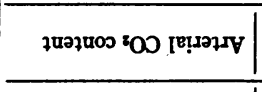 & 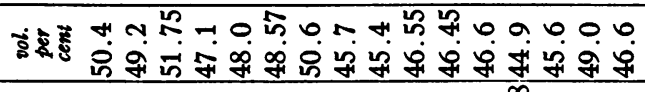 \\
\hline əsฐnd & 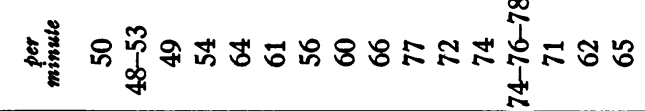 \\
\hline $248 \div \div \mathrm{M}$ & 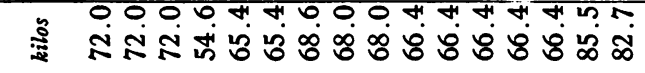 \\
\hline 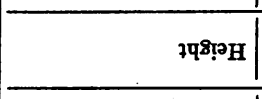 & 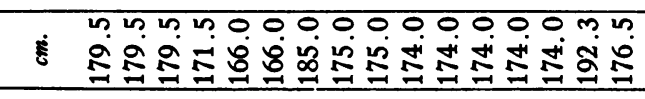 \\
\hline 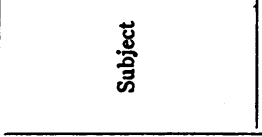 &  \\
\hline คัّ & 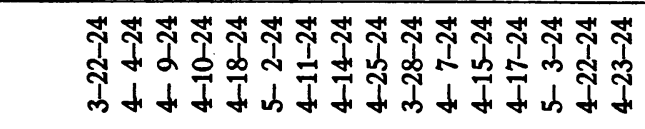 \\
\hline
\end{tabular}




\begin{tabular}{|c|c|c|c|c|c|}
\hline 蒙范范 & ษ & $\stackrel{2}{n}$ & $\underset{\sim}{\dot{j}}$ & $\stackrel{\infty}{i}$ & $\stackrel{R}{i}$ \\
\hline 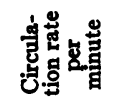 & $\stackrel{\Xi}{\vdots}$ & $\stackrel{?}{a}$ & $\stackrel{\infty}{a}$ & $\stackrel{\circ}{\circ}$ & $\vec{\infty}$ \\
\hline 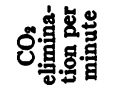 & ن & 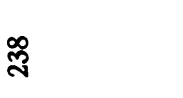 & స్తి & $\approx$ & $\bar{a}$ \\
\hline 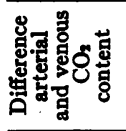 & 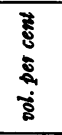 & 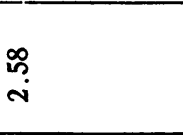 & $\underset{i}{I}$ & $\dddot{q}$ & ì \\
\hline  & 害 & $\rightarrow N m$ m n & HNm & HNm th & HNMA DN \\
\hline \multirow{4}{*}{ 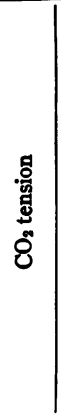 } & $\begin{array}{l}\infty \\
0 \\
0 \\
0\end{array}$ & $\stackrel{?}{?}$ & $\stackrel{+!}{\text { in }}$ & in & ơ \\
\hline & 密 & 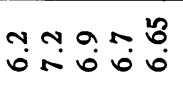 & 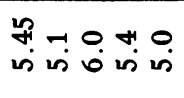 & 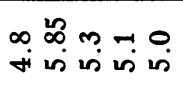 & 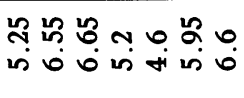 \\
\hline & $\underset{|c|}{\infty}$ & 年尔尔尔尔 & 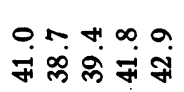 & 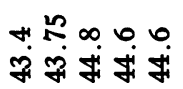 & 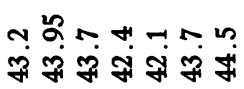 \\
\hline & 密 & - & ஜூ & $\begin{array}{l}0 \\
0 \\
\infty\end{array}$ & 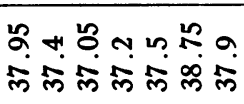 \\
\hline 点密名 & 害 & TNMU & HNm n & Henth & HNMt HOR \\
\hline 莺 & 2. & $\stackrel{\infty}{n}$ & $\mathbb{N}$ & ボ & ล \\
\hline 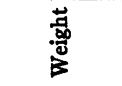 & $\stackrel{5}{2}$ & $\bar{a}$ & 8 & $\because$ & 8 \\
\hline 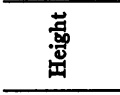 & 8 & $\stackrel{\infty}{\circledR}$ & 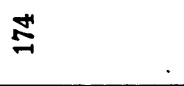 & $\stackrel{ \pm}{=}$ & $\underset{ت}{ \pm}$ \\
\hline ڤึ & & $\Sigma$ & $\dot{\Sigma}$ & 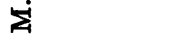 & $\Sigma$ \\
\hline 葪 & & $\begin{array}{l}\dot{0} \\
\dot{4} \\
\dot{1}\end{array}$ & $\begin{array}{l}\dot{4} \\
\dot{4}\end{array}$ & $\begin{array}{l}\text { 㟝 } \\
\text { 岀 }\end{array}$ & $\begin{array}{l}\dot{\dot{4}} \\
\dot{4}\end{array}$ \\
\hline ڤัّ & 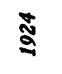 & i⿱ & in & $\stackrel{\infty}{1}$ & $\frac{0}{b}$ \\
\hline
\end{tabular}




\begin{tabular}{|c|c|c|c|c|}
\hline$\frac{ \pm}{i}$ & in & $\underset{i}{8}$ & 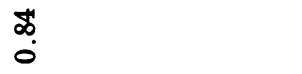 & $\stackrel{8}{-1}$ \\
\hline$\frac{a}{a}$ & $\begin{array}{l}\text { के } \\
\text { in }\end{array}$ & $\begin{array}{l}\infty \\
\infty \\
0\end{array}$ & 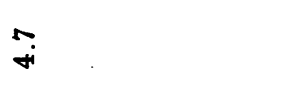 & 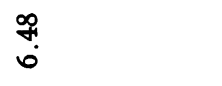 \\
\hline$\stackrel{n}{2}$ & 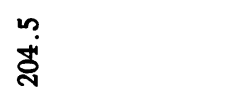 & ஸุ & $\stackrel{5}{\circ}$ & $\stackrel{2}{1}$ \\
\hline$\stackrel{0}{i}$ & f̣ & $\stackrel{8}{i}$ & $\stackrel{\infty}{\rightarrow}$ & $\hat{i}$ \\
\hline Nmtin & $\Rightarrow \quad n=0$ & $N m+$ & $-N m \quad 0 N \infty$ & $\rightarrow N M H \ln 0$ \\
\hline in & $\begin{array}{l}\stackrel{2}{n} \\
\infty\end{array}$ & $\stackrel{m}{n}$ & qి & $\stackrel{?}{\mathfrak{2}}$ \\
\hline 赵 & 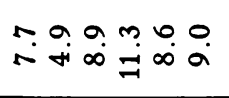 & Hั0 & 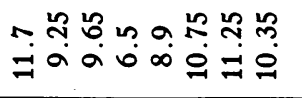 & 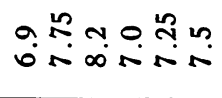 \\
\hline 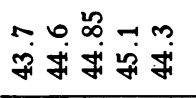 & 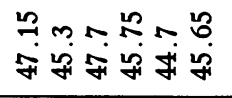 & 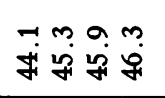 & 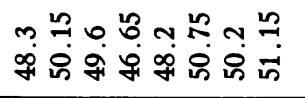 & 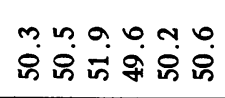 \\
\hline 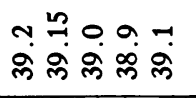 & 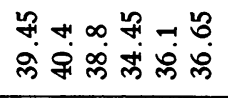 & Nִ & 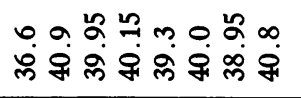 & 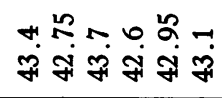 \\
\hline HNm H m & $\operatorname{tantin} 0$ & $\begin{array}{c}n+n m+ \\
\end{array}$ & HNMt县舟 & $\rightarrow N m+\cos 0$ \\
\hline$\hat{0}$ & กิ & $\stackrel{\infty}{+}$ & $\overparen{ర}$ & ชั \\
\hline オ゙ & N & $\begin{array}{l}0 \\
\infty\end{array}$ & $\overbrace{\infty}^{n}$ & $\ddot{n}$ \\
\hline$\stackrel{ \pm}{ \pm}$ &  & $\stackrel{\infty}{\infty}$ & ñ & $\stackrel{1}{\circ}$ \\
\hline$\dot{\Sigma}$ & $\dot{\Sigma}$ & $\dot{\Sigma}$ & $\dot{\Sigma}$ & $\dot{\Sigma}$ \\
\hline 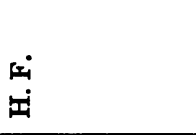 & $\stackrel{\dot{3}}{\dot{3}}$ & 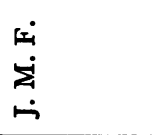 & $\begin{array}{l}\dot{2} \\
ن \\
ن \\
ن\end{array}$ & $\underset{ن}{\dot{\Sigma}}$ \\
\hline q & 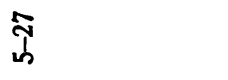 & i⿱ & I & $\mathfrak{b}$ \\
\hline
\end{tabular}




\begin{tabular}{|c|c|c|c|c|c|}
\hline 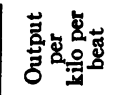 & ن & $\underset{-}{\exists}$ & $\stackrel{\exists}{\sharp}$ & in & $\stackrel{\infty}{\longrightarrow}$ \\
\hline 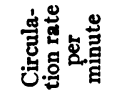 & $\stackrel{8}{*}$ & is & $\stackrel{n}{0}$ & $\underset{0}{\ddot{0}}$ & $\stackrel{7}{0}$ \\
\hline 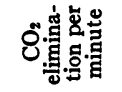 & ن & $\stackrel{m}{\mathrm{i}}$ & ஜृ. & 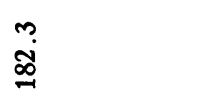 & นุ \\
\hline 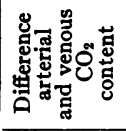 & 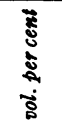 & $\stackrel{?}{?}$ & 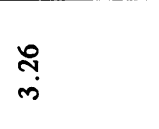 & $\stackrel{n}{i}$ & $\ddot{\circ}$ \\
\hline 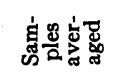 & है & HNm no & $\Rightarrow m+$ & NMtin & HNM no \\
\hline \multirow{4}{*}{ 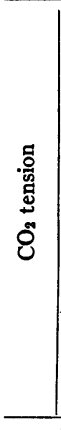 } & 象 & $\begin{array}{l}\infty \\
\infty\end{array}$ & $\stackrel{+}{\infty}$ & $=$ & $\stackrel{\infty}{\infty}$ \\
\hline & 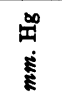 & 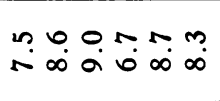 & $\vec{\infty} \stackrel{\infty}{\infty} \underset{\infty}{\infty} \stackrel{+}{\infty}$ &  &  \\
\hline & 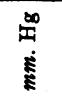 & 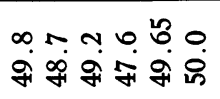 & 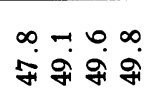 &  & 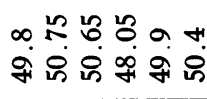 \\
\hline & 密 & 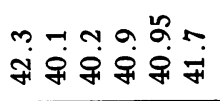 & 苟尔芦芦 & 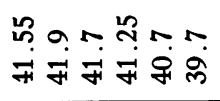 & 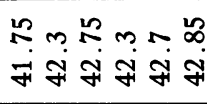 \\
\hline 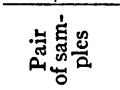 & 气 & $\operatorname{tanting}$ & $H N m+$ & $\Rightarrow N M+\sin 0$ & $H N M$ H n \\
\hline 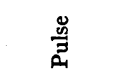 & ڤั. & 8 & : & $\overline{6}$ & オర \\
\hline 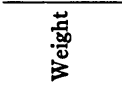 & $\stackrel{2}{2}$ & $\hat{0}$ & $\hat{0}$ & $\overrightarrow{8}$ & $\vec{\infty}$ \\
\hline 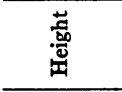 & ह & $\underset{\sigma}{\mathbb{t}}$ & 苂 & 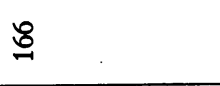 & $\stackrel{\infty}{\infty}$ \\
\hline 品 & & $\dot{\Sigma}$ & $\dot{\Sigma}$ & $\sum$ & $\Sigma$ \\
\hline 芯 & & $\begin{array}{l}\dot{2} \\
\dot{z} \\
\dot{r}\end{array}$ & $\begin{array}{l}\dot{2} \\
\dot{z} \\
\dot{4}\end{array}$ & $\dot{4}$ &  \\
\hline$\stackrel{\Xi}{\Xi}$ & $\stackrel{\Xi}{\Xi}$ & $\frac{9}{1}$ & $\frac{m}{b}$ & $\bar{b}$ & $\frac{7}{b}$ \\
\hline
\end{tabular}




\begin{tabular}{|c|c|c|c|c|c|}
\hline & $\vec{n}$ & $\stackrel{\infty}{-\infty}$ & $\stackrel{\overbrace{}}{\circ}$ & $\stackrel{\infty}{-}$ & $\stackrel{\infty}{=}$ \\
\hline 免 & $\stackrel{\infty}{\stackrel{\infty}{\Lambda}}$ & $\stackrel{\infty}{\square}$ & $\stackrel{q}{q}$ & $\underset{\infty}{m}$ & $\stackrel{5}{*}$ \\
\hline ฉี & శ్సి & $\stackrel{m}{2}$ & $\stackrel{n}{\dot{s}}$ & $\stackrel{0}{\stackrel{n}{n}}$ & $\ddot{\circ}$ \\
\hline$\underset{i}{*}$ & 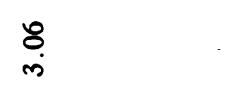 & $\stackrel{\infty}{\infty}$ & 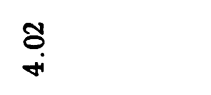 & $\underset{\sim}{\stackrel{\sim}{i}}$ & $\underset{\sim}{\stackrel{\sim}{\sim}}$ \\
\hline$m+\sin 0$ & HNMH & NOH & -NMtin & $\Rightarrow m+$ & HNM \\
\hline $\begin{array}{l}\infty \\
\infty \\
\infty\end{array}$ & $\stackrel{\vec{\infty}}{r}$ & $\stackrel{\leftrightarrow}{\sim}$ & ă & $=$ & $=$ \\
\hline 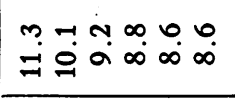 & م: & 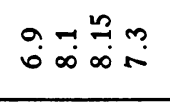 & 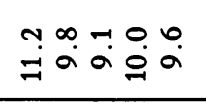 & 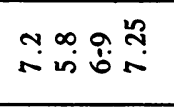 & 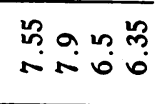 \\
\hline  & 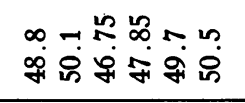 & 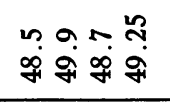 & 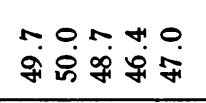 & 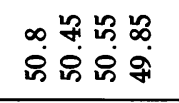 &  \\
\hline 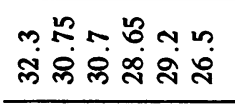 & 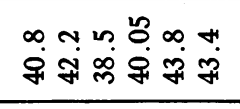 & 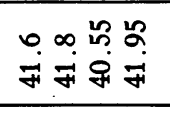 &  & 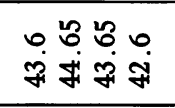 & 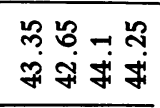 \\
\hline -Notino & HNMtino & Hama & HNOt & HNOH & HNA \\
\hline H & in & 8 & H & $\ddot{B}$ & 8 \\
\hline$\Sigma$ & $\stackrel{\infty}{\infty}$ & $\stackrel{8}{8}$ & $\ddot{8}$ & 8 & 8 \\
\hline$\stackrel{\infty}{\exists}$ & 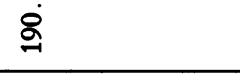 & $\stackrel{2}{g}$ & $\stackrel{2}{\geq}$ & $\Xi$ & $\Xi$ \\
\hline$\dot{z}$ & $\dot{z}$ & $\dot{x}$ & $\dot{z}$ & $\dot{x}$ & $\dot{x}$ \\
\hline $\begin{array}{l}\dot{4} \\
ن \\
\dot{4} \\
\end{array}$ & $\begin{array}{l}\dot{0} \\
\dot{\phi} \\
\dot{B} \\
\end{array}$ & $\begin{array}{l}\stackrel{\leftrightarrow}{\longrightarrow} \\
\stackrel{4}{4}\end{array}$ & 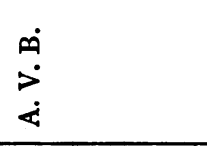 & $\dot{A}$ & $\dot{A}$ \\
\hline$\frac{m}{b}$ & $\frac{\pi}{b}$ & $\frac{a}{b}$ & 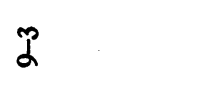 & $I$ & $p$ \\
\hline
\end{tabular}




\begin{tabular}{|c|c|c|c|c|c|c|}
\hline 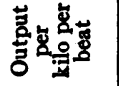 & $\dot{s}$ & $\stackrel{a}{a}$ & 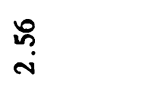 & $\stackrel{n}{?}$ & $\stackrel{\infty}{-}$ & $\vec{m}$ \\
\hline 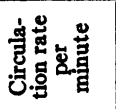 & 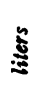 & $\underset{m}{m}$ & $\vec{n}$ & $\stackrel{m}{m}$ & $\ddot{B}$ & $\stackrel{4}{i}$ \\
\hline  & $\dot{s}$ & $\underset{\sim}{\mathscr{D}}$ & $\stackrel{0}{\circ}$ &  & ธ్ర & $\underset{\sigma}{0}$ \\
\hline 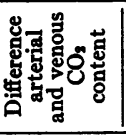 & 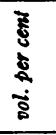 & $\stackrel{0}{\sim}$ & $\underset{\sim}{\mathbb{i}}$ & $\underset{\text { ì }}{\infty}$ & $\stackrel{\&}{\sim}$ & $\stackrel{0}{i}$ \\
\hline 息影它总 & 离 & $H N M+$ & -NM & Noth & $\operatorname{ta}$ thin & HNm \\
\hline 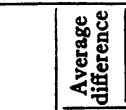 & 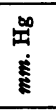 & in & $\stackrel{\infty}{0}$ & 2ุ & ণి & in \\
\hline 总 & జึ: & 象 m 0 & 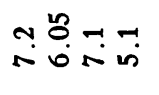 & ب & 뭄ํำ & ن \\
\hline 8ิ & 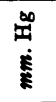 &  & 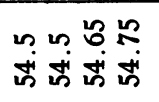 & 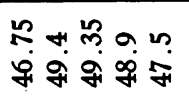 & $\begin{array}{l}\text { n } \\
\text { in }\end{array}$ & 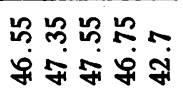 \\
\hline $\begin{array}{l}3 \\
\frac{3}{8} \\
\end{array}$ &  & 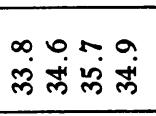 & 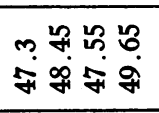 & 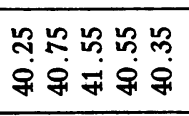 & ח & 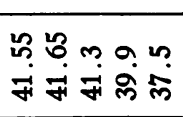 \\
\hline 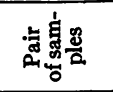 & है & $\pi N m$ & $\rightarrow N m+$ & HNm $n$ & HNMH n & Ham \\
\hline 兽 & t) & $\because$ & 오 & 8 & $R$ & ชั \\
\hline 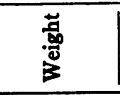 & 产 & ํ. & 30 & in & in & กี \\
\hline  & (E) & $\cong$ & 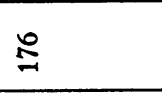 & $\underset{-8}{8}$ & 8 & జֶ. \\
\hline ळ & & $\dot{\Sigma}$ & $\dot{\Sigma}$ & si & si & si \\
\hline 蒿 & & $\begin{array}{l}\dot{\varphi} \\
\dot{\Sigma} \\
\dot{<}\end{array}$ & $\begin{array}{l}\dot{9} \\
\dot{0} \\
\dot{n}\end{array}$ & $\begin{array}{l}\dot{\Sigma} \\
\text { si } \\
\dot{\Sigma}\end{array}$ & $\begin{array}{l}\text { 出 } \\
\dot{1} \\
\dot{\Sigma}\end{array}$ & $\begin{array}{l}\dot{n} \\
\dot{4} \\
\dot{s}\end{array}$ \\
\hline$\stackrel{\Xi}{\sharp}$ & $\underset{\Xi}{*}$ & $i$ & $I$ & $\bar{b}$ & $\frac{0}{16}$ & $\frac{9}{1}$ \\
\hline
\end{tabular}


high and a low resting blood flow are both right. The series is large enough so that several individuals of both types have been encountered, as well as variations between the two extremes. The majority of the determinations have fallen within Y. Henderson's estimate (15) of a cardiac output of 1.5 to $2.0 \mathrm{cc}$. per kilo per beat. Five subjects have had one or more determinations that were below these figures and four have had larger outputs.

In at least four individuals, the small cardiac output under conditions of rest would appear to render impossible Y. Henderson's conclusion (15) that the stroke volume of the heart is a nearly constant quantity for each individual, it being too small to permit sufficient ventilation of the tissues during strenuous exercise. In the others, a constant stroke volume would be possible.

No correlation between the volume of the blood flow and any other factor, such as type of build or athletic ability is apparent.

\section{BIBLIOGRAPHY}

1. Burwell, C. S. and Robinson, G. C. Jour. Clin. Invest., 1924, i, 47.

2. Christianson, J., Douglas, C. G. and Haldane, J. S. Jour. Physiol., 1914, xxxviii, 265.

3. Haldane, J. S., and Priestley, J. G. Jour. Physiol., 1905, xxxii, 225.

4. Henderson, Y., and Prince, A. L. Jour. Biol. Chem., 1917, xxxii, 325.

5. Henderson, Y. Arch. Neerland. de Physiol., 1922, vii, 378.

6. Meakins, J., and Davies, H. W. Heart, 1922, ix, 191.

7. Haldane, J. S. Respiration, New Haven, 1922, 136.

8. Hendry, M. F., Carpenter, T. M., anḑ Emmes, L. E. Boston Med. and Surg. Jour., 1919, clxxxi, 285.

9. Bock, A. V., Field, H., Jr., and Adair, G. S. Jour. Metabolic Research, 1923, iv, 27.

10. Bock, A. V., Field, H., Jr., and Adair, G. S. Jour. Biol. Chem., 1924, lix, 363.

11. Bock, A. V., and Field, H., Jr. Jour. Biol. Chem., in press.

12. Peters, J. P., Barr, D. P., and Rule, F. D. Jour. Biol. Chem., 1921, xlv, 489.

13. Campbell, J. M. H., Hunt, C. H., and Poulton, E. P. Jour. Path. and Bact., 1923, xxvi, 234.

14. Van Slyke, D. D. Abs. Proc. Assoc. Amer. Phys., Jour. Amer. Med. Assoc., 1924, lxxxii, 1808.

15. Henderson, Y. Physiological Reviews, 1923, iii,165. 